\title{
Uniqueness of RNA Coliphage $Q \beta$ Display System in Directed Evolutionary Biotechnology
}

\author{
Godwin W. Nchinda ${ }^{1,2} \oplus$, Nadia Al-Atoom ${ }^{3}$, Mamie T. Coats ${ }^{4}$, Jacqueline M. Cameron ${ }^{5}$ \\ and Alain B. Waffo ${ }^{5, *}$ (D) \\ 1 Laboratory of Vaccinology and Biobanking, International Reference Centre CIRCB), \\ BP 3077 Yaoundé, Cameroon; nsehleseh@gmail.com \\ 2 Department of Pharmaceutical Microbiology \& Biotechnology, Nnamdi Azikiwe University, \\ 420110 Awka, Nigeria \\ 3 Department of Pathobiology, College of Veterinary Medicine, Tuskegee University, Tuskegee, AL 36088, USA; \\ nal-atoom7321@tuskegee.edu \\ 4 Clinical and Diagnostic Sciences, University of Alabama at Birmingham, Birmingham, AL 35294, USA; \\ mamiec@uab.edu \\ 5 Biochemistry and Molecular Biology, Indiana University School of Medicine, Indianapolis, IN 46202, USA; \\ jacmcame@iu.edu \\ * Correspondence: abopdaw@iu.edu; Tel.: +1-317-274-9640
}

check for updates

Citation: Nchinda, G.W.; Al-Atoom, N.; Coats, M.T.; Cameron, J.M.; Waffo, A.B. Uniqueness of RNA Coliphage $\mathrm{Q} \beta$ Display System in Directed Evolutionary Biotechnology. Viruses 2021, 13, 568. https://doi.org/ $10.3390 / \mathrm{v} 13040568$

Academic Editor: Valery A. Petrenko

Received: 19 February 2021

Accepted: 25 March 2021

Published: 27 March 2021

Publisher's Note: MDPI stays neutral with regard to jurisdictional claims in published maps and institutional affiliations.

Copyright: (c) 2021 by the authors. Licensee MDPI, Basel, Switzerland. This article is an open access article distributed under the terms and conditions of the Creative Commons Attribution (CC BY) license (https:/ / creativecommons.org/licenses/by/ $4.0 /$ )
Abstract: Phage display technology involves the surface genetic engineering of phages to expose desirable proteins or peptides whose gene sequences are packaged within phage genomes, thereby rendering direct linkage between genotype with phenotype feasible. This has resulted in phage display systems becoming invaluable components of directed evolutionary biotechnology. The M13 is a DNA phage display system which dominates this technology and usually involves selected proteins or peptides being displayed through surface engineering of its minor coat proteins. The displayed protein or peptide's functionality is often highly reduced due to harsh treatment of M13 variants. Recently, we developed a novel phage display system using the coliphage $Q \beta$ as a nanobiotechnology platform. The coliphage $\mathrm{Q} \beta$ is an RNA phage belonging to the family of Leviviridae, a long investigated virus. $\mathrm{Q} \beta$ phages exist as a quasispecies and possess features making them comparatively more suitable and unique for directed evolutionary biotechnology. As a quasispecies, $\mathrm{Q} \beta$ benefits from the promiscuity of its RNA dependent RNA polymerase replicase, which lacks proofreading activity, and thereby permits rapid variant generation, mutation, and adaptation. The minor coat protein of $Q \beta$ is the readthrough protein, $A_{1}$. It shares the same initiation codon with the major coat protein and is produced each time the ribosome translates the UGA stop codon of the major coat protein with the of misincorporation of tryptophan. This misincorporation occurs at a low level (1/15). Per convention and definition, $\mathrm{A}_{1}$ is the target for display technology, as this minor coat protein does not play a role in initiating the life cycle of $Q \beta$ phage like the pIII of M13. The maturation protein $\mathrm{A}_{2}$ of $\mathrm{Q} \beta$ initiates the life cycle by binding to the pilus of the $\mathrm{F}^{+}$host bacteria. The extension of the $A_{1}$ protein with a foreign peptide probe recognizes and binds to the target freely, while the $\mathrm{A}_{2}$ initiates the infection. This avoids any disturbance of the complex and the necessity for acidic elution and neutralization prior to infection. The combined use of both the $A_{1}$ and $A_{2}$ proteins of $Q \beta$ in this display system allows for novel bio-panning, in vitro maturation, and evolution. Additionally, methods for large library size construction have been improved with our directed evolutionary phage display system. This novel phage display technology allows 12 copies of a specific desired peptide to be displayed on the exterior surface of $Q \beta$ in uniform distribution at the corners of the phage icosahedron. Through the recently optimized subtractive bio-panning strategy, fusion probes containing up to 80 amino acids altogether with linkers, can be displayed for target selection. Thus, combined uniqueness of its genome, structure, and proteins make the $Q \beta$ phage a desirable suitable innovation applicable in affinity maturation and directed evolutionary biotechnology. The evolutionary adaptability of the $Q \beta$ phage display strategy is still in its infancy. However, it has the potential to evolve functional domains of the desirable proteins, glycoproteins, and lipoproteins, rendering them superior to their natural counterparts. 
Keywords: M13; pIII; Q $\beta$; Leviviridae; $\mathrm{A}_{1} ; \mathrm{A}_{2}$; replicase; UGA; tryptophan; icosahedron; evolutionary biotechnology; in vitro evolution; affinity maturation; $\mathrm{F}^{+}$, minor coat; major coat; fitness landscape; quasispecies

\section{Introduction}

Phage display and engineering are powerful tools in synthetic biology and directed evolutionary biotechnology [1-5]. A phage represents a unique, yet miniature, simple model system that is easy and safe to manipulate [6-8]. Structurally, the minor and major coat proteins of phages can be genetically modified to encapsulate foreign peptides and present them upon their surface $[9,10]$. The modified phage genome contains the gene of the surface exposed foreign peptides. The linkage between the modified phage genome and the surface exposed foreign peptide is a unique and powerful tool for directed evolutionary study $[11,12]$. Through combinatorial cDNA libraries, room is created for more genetic insertions, with the possibility of expressing and exposing a further expanded novel phenotype. The diversity of a library in in vitro directed evolution is of great importance, as it increases the number of probes exposed, as well as diversity in target(s) directed specificity. Like viruses, phages may contain a DNA genome, which replicates using DNAdependent-DNA-polymerase (DdDp) or an RNA genome, which uses an RNA-dependentRNA-polymerase (RdRp) [13-16]. The RdRp and DdDp function differently and can affect the diversity of the library. The DdDp is known to contain a proofreading activity, which can stabilize or significantly reduce the diversity of a library $[17,18]$. However, the RdRp lacks proofreading activity, which in effect drives library diversity through error prone phage replication, and promoting a rapid evolution $[19,20]$.

Bacteriophages were discovered independently by Felix d'Herelle and Frederick Twort in the 19th century, and have since been intensively studied [21-24]. Phage classification and genetics are well understood, but only M13 has been dominantly used in display and surface engineering [1-5,25-28]. Given the broad range of diverse phage structure and organization, it seems likely that directed evolution is applicable with other type of phages [29]. However, M13, the first phage used for foreign peptide display, remains dominant in the phage display field and engineering biotechnology [1-10]. M13 is cylindrical in shape, being $1 \mathrm{um}$ in length, less than $10 \mathrm{~nm}$ in diameter and belongs to the group of phages referred to as Inoviridae, bearing a single stranded circular DNA core [30-33]. The M13 phage genome is about $6.4 \mathrm{~kb}$, encoding for five different proteins, including p3, p6, p7, p8, and p9. Thus far, DNA phage M13 and phagemids have been commonly used despite tremendous advances in phage research [34-37]. The phage M13 minor protein p3 or pIII is commonly used to expose foreign peptides [36]. The protein pIll functionally directs virion tropism and infection by recognizing and binding to the pilus of $\mathrm{F}^{+}$bacteria host. The dual functions of pIII in the phage life cycle limits its applicability in phage display biotechnology by reducing its efficiency during panning and amplification on target $[1-10,36]$. Additionally, the infectivity of the recombinant phages can be drastically reduced when pIII displayed foreign peptide probe are bound to their respective target. This necessitates harsh treatment, including heat or acidic elution and neutralization of the complex probe-target for M13 $[1,8]$. The phage $\mathrm{Q} \beta$ belongs to Leviviridae family, with a small positively stranded RNA virus, with a $4.2 \mathrm{~kb}$ genome encoding 4 proteins including the coat $(C p)$, maturation $\left(A_{2}\right)$, readthrough $\left(A_{1}\right)$, and replicase (RdRp) protein [38]. As an RNA virus, the $Q \beta$ phage possesses the replicase protein, a key feature making it suitable for rapid evolution and adaptation [39]. The $\mathrm{Q} \beta$ phage replicase is devoid of proofreading activity during replication, resulting in heightened mutation rates, simulating the affinitymaturation processes, promoting directed evolutionary biotechnology $[19,20,39-42]$.

This review addresses the uniqueness of the novel RNA coliphage $Q \beta$ display system, specifically as an alternative to the traditional M13 display technology. Recently, this alternative system has shown progress in its application for immunogen display and monitoring 
of immunity of infectious diseases at point of care. We will discuss the unique capability of $\mathrm{Q} \beta$ in library display, developed bio-panning for screening and hybrid phage amplification. We will also stress some major applications of the $Q \beta$ display system, such as presenting various types of surface proteins as immune check point inhibitors, antiviral therapy, and in the development of point of care nanobiotechnology using directed evolution.

\section{RNA Evolution}

\subsection{Overall Evolution}

Referring to Darwin, evolution was defined as the fitness of any living entity (wherever) which can survive and replicate under the present conditions. It is the ability to change (phenotype), adapt, and to replicate the genetic materials (genotype) through natural pressure to achieve the so-called "natural selection" [43,44]. This fitness went from a simple single concept to a complex fitness landscape, representing the quantitative living system [45-47]. As defined, the landscape is directly proportional to the genomic size. Therefore, the fitness landscape is complex for eukaryotic systems and limited physically by the huge number of different methods and sequences. Viruses represent a powerful tool to assess the fitness landscape, particularly phages. Bacteriophages represent a safe dynamic tool that would continue to drive and empower this concept. Phages are perfect natural biological tools for directed evolution studies. The power of the fitness landscape does not rely only on the genotype, but on the ability of the replicative machinery to do the replication process (DNA-based or RNA-based). The development of phage display technology has expanded the fitness landscape concept to include the ability to prepare, expose, use for screening different size, and format libraries of peptides on the phages. This is the insertion of synthetic biology in the field of biotechnology and in vitro evolution (IVE) into the era of evolutionary biotechnology, specifically the identification of desired functionalities from a single library of variants. IVE is efficient process, especially when considering RNA-based replication systems and their associated suitable features. Additionally, the coliphage $\mathrm{Q} \beta$, like other RNA viruses, has the unique position of belonging to the fitness landscape and performing as a rapid IVE tool.

\subsection{Evolution with RNA Viruses}

RNA viruses with their small genomes represent a true model of rapid evolution, yielding a large population size with inconsistency in the fitness landscape and short replication time [48]. The RNA virus population is often named the "quasispecies", referring to the fact that the genomics of the population consist of a mutant spectrum rather than a single species with identical nucleotide sequence [49-53]. The existence of RNA viruses as a mutant spectra is a direct consequence of evolution. Many studies have shown the high rate of nucleotide misincorporation during replication from the parental template to the progeny viral genomes. The quasispecies can have advantages and disadvantages for the host (human) and the virus. An accumulation of mutations can lead to extinction (death) of the virus or other biological implications, like changing the cell tropism or host range and overcoming selective constraints. These selective constraints include antiviral drugs and immune therapy molecules (specific antibodies). The quasispecies existence of RNA viruses make it very difficult to detect and challenging to prevent and treat. Mutant swarms of virus specific targets can compromise the detection, especially at point of care.

There is a need to conceptualize and develop models of detection, treatments or prevention that will consider the viral quasispecies evolution. The uniqueness of the $Q \beta$ phage rapid evolution can fulfill this requirement and its adaptive potential can bridge the knowledge gap in combating the mutant clouds of infectious RNA viruses. The phage Q $\beta$ would not be an exception to the rules of RNA viruses, but would be a powerful tool for an IVE study instead. In fact, RNA $Q \beta$ phage could be used as a toolkit that would employ and exploit its unique features in the directed evolutionary process [54-58]. 


\subsection{An Emphasis of Evolution with Coliphage $Q \beta$}

The $\mathrm{Q} \beta$ phage possesses the major features of viral quasispecies. Specifically, great genetic variation due to the promiscuity of its RdRp, which lacks proofreading activity; competition and selection ability; viral fitness and effect of the population size; bottleneck events; fitness gain and change [47-55]. Genetic variation was observed with accumulation of point mutations in foot and mouth disease virus (FMDV), an evolutionary study with few internal genomic deletions that were severely infectious and killed cells between several passages (143 to 260) $[47,50,52,53]$. Exhibiting genetic variation in order to gain more function in the life cycle is ideal for the $Q \beta$ phage, as it is necessary to evolve and adapt to the new target during panning. Recently, we described a benchtop in vitro evolution system with RNA Q $\beta$ displaying a randomized VP1 GH loop peptide of FMDV [55]. The gene fusion of $A_{1}$ and $G H$ loop was stable in a replicating component that yields hybrid phages. The $Q \beta$ displaying on its surface localized the FMDV VP1 GH loop and crossreacted with an anti-FMDV monoclonal antibody $(\mathrm{mAb}) \mathrm{SD} 6$ and was found to decorate the 12 corners of the phage icosahedron. Hybrid phages presenting the GH loop selected under evolutionary pressure revealed a non-canonical (Arg-Gly), but essential epitope, for the mAb SD6 recognition motif [55]. Additionally, the competition amongst mutants for the target will agree with the Red Queen hypothesis, that states that occasionally superior mutants arise and exclude others by competition. Recently, foreign peptide genes, up to 80 mer, have been stably inserted into the phage genome and exposed to its surface. A library format with this size can be inserted into the phage as well [56,57]. In combination with innovative emergent technology, an intelligent library design avoiding inactive variants can be developed. Designing active variants within a library will give additional advantages to RNA virus evolution and strengthen IVE. The complexity of the mutant spectrum and the RNA phage display can act as a combination therapy and possibly ideal against RNA virus infections. The $Q \beta$ phage is unique, thus proving to be a major candidate, as well as perfect tool for directed evolution and IVE.

\section{Uniqueness of the Biology Coliphage $Q \beta$}

The $\mathrm{Q} \beta$ coliphage belongs to the family of Leviviridae and exhibits a positive-sense single stranded RNA genome molecule (+ssRNA) [59]. Morphologically, $Q \beta$ particles are icosahedral in shape with $25 \mathrm{~nm}$ in diameter and a $\mathrm{T}=3$ triangulation [60]. $\mathrm{Q} \beta$ is very simple with 4.1 kilobases genome (Figure 1 ) encoding for only four proteins including the maturation protein $\left(A_{2}\right)$, the coat protein $(C p)$, the minor structural protein $\left(A_{1}\right)$, and the replicase subunit $(\mathrm{Rp})[61]$.

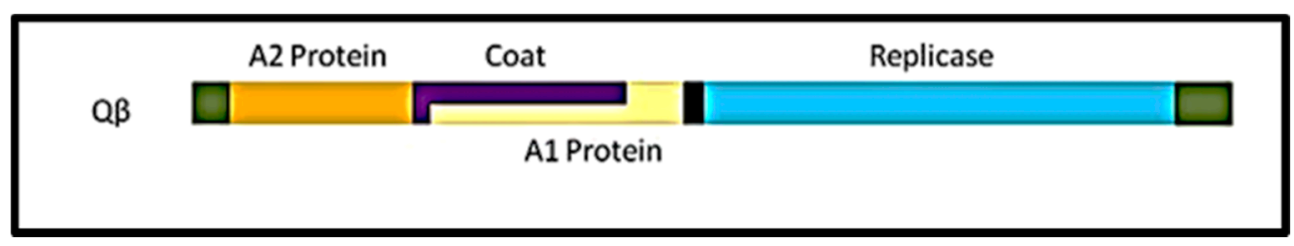

Figure 1. Genome organization of the RNA coliphage $Q \beta$. $A_{2}$ protein gene or maturation gene (from 62-1321 bases); $\mathrm{C}$ p or major coat protein gene (from 1345-1743 bases); $\mathrm{A}_{1}$ protein gene or readthrough (from 1345-2331 bases); Replicase or the $\beta$-subunit gene of the RNA-dependent-RNA-polymerase (from 2353-4119 bases). The 5' and 3" ends are flanked by non coding bases like any other open reading frame on this genome.

\subsection{Coliphage $Q \beta$ Life Cycle \\ 3.1.1. Overall Cycle}

$\mathrm{Q} \beta$ phage infects various bacterial hosts with pilus structures. The so-called appendage pilus is commonly used for conjugation and plasmid transfer in those bacteria [62] Physiologically, the F-pili functions to bring together the donor and recipient bacteria for the purpose of transferring the appropriate genetic material [63]. After attachment to the 
pili on the host cell surface, the $Q \beta$ phage particles eject the RNA- $A_{2}$, allowing the RNA to repurpose the gene-transfer machinery for delivery inside the target host cell. The mechanism of ssRNA ejection from the capsid and injection into the host is poorly understood, due in part to the high level of secondary structure of the RNA that it is assigned to the type like a DNA plasmid transfer [64]. $Q \beta$ is classified as a male dependent virus, since it uses F-pili to initiate infection. As a (+) ssRNA, Q $\beta$ will serve as mRNA for early protein synthesis like the subunit of the polymerase complex (Rp) and a template for multiple genomic copy synthesis [65]. The life cycle is promoted by the secondary structure of the RNA [65]. Engineering some domains of this ssRNA has substantially modified the phage titer over the time. Excess phage progeny components can disturb the host functions or lyse it. The mechanism involved in the final step, following assembly of phage components into new progenies, is not clear for $Q \beta$. Freely generated progenies would, in turn, start their infection cycle by adsorbing to the F-pili. Additionally, the $\mathrm{Q} \beta$ cycle takes about $50 \mathrm{~min}$ at $37^{\circ} \mathrm{C}$ and releases about 100 progenies [66-68].

\subsubsection{Proteins Involved in the Life Cycle and Functions}

The $\mathrm{A}_{2}$ protein allows each phage particle to be adsorbed to the F-pili. The $\mathrm{A}_{2}$ protein is complexed with $Q \beta$ phage RNA, and is always cleaved to eject it from the particle. There is no distinguishable lysis protein (LP) gene in the $Q \beta$ genome. Recently, the $A_{2}$ protein was found to carry out cell lysis through another pathway [69]. Thus, the $A_{2}$ protein plays two critical functions in the phage cycle consisting of initiation and termination. The Rp is the $\beta$-subunit of the RNA-dependent-RNA-polymerase, (RdRp) together with the host elongation factors EF-Tu, EF-Ts, and the ribosomal protein S1 [70]. The Rp hijacked those host proteins and exploited them to replicate the phage's genomic RNA. The function of the $A_{1}$ is not entirely clear, but seems to play a role in the initiation of mature particles assembly. The $\mathrm{Cp}$ seems not to have a role in the infectivity process, other than to protect the phage RNA.

\subsubsection{Unknown or Unclear Part of the Cycle}

The host penetration by $Q \beta$ RNA, as well as the liberation of the phage progenies, is unclear, but well adapted in many bacteria study thus far. The process of $\mathrm{A}_{2}$ cleavage and genome ejection is also not clear, but could be associated with the spontaneous retraction of the pilus. The mechanism of the $\beta$-subunit recruiting the host machinery for phage RNA replication is also not well reported, however, is adapted to the RNA replication system. The portion of the phage RNA recognized by the Rp is also not known.

\subsection{Coliphage $Q \beta A_{2}$ Protein}

\subsubsection{Structure and Domain}

The structure of the $A_{2}$ protein was recently resolved by Rumnieks and Tars [66-68]. Q $\beta$ contains only one copy of this protein, which is about $48.55 \mathrm{kDa}$. $\mathrm{A}_{2}$ is highly asymmetric in shape and spans $110 \AA$ in length while bound to the phage genome. The $\mathrm{A}_{2}$ takes the position of a Cp-dimer and disrupts the perfect icosahedral symmetric shape of the capsid with the triangulation number of $\mathrm{T}=3$ [71-73]. The structural organization of the $\mathrm{A}_{2}$ has two distinct regions, namely an $\alpha$-helical part (with four-helix core) and a $\beta$ stranded part (with seven-stranded sheet). Additionally, at the tip of the $\mathrm{A}_{2}$ protein is a central portion with a five-stranded sheet [66,74].

\subsubsection{Functional Domains}

The bond between the $\mathrm{A}_{2}$ protein and the phage RNA is through two positively charged areas on opposite sides of the $\alpha$-helix. The $A_{2}$-RNA complex provides protection to the genome against external ribonucleases and also initiates the formation of mature nascent virions in the infected host. The complex enters the packaged capsid where the $A_{2}$ remains, partially exposed upon the phage surface. In this position, the rest of the $A_{2}$ protein within the phage capsid binds to each of the surrounding protein coat dimers [74]. 
Although the interaction between $\mathrm{A}_{2}$ and the $\mathrm{Cp}$ dimers is very weak, together with the charge mediated interaction with RNA, it renders the mature $A_{2}$ protein modestly soluble and difficult to purify. The position of the $\mathrm{A}_{2}$ allows for it to act as a minor structural constituent as the $A_{1}$. The $A_{2}$ drives phage tropism during infection by adsorbing the phage particles onto bacteria pili. The F-pili serves as a cellular receptor for the $Q \beta$ phage. In addition, the mature $\mathrm{A}_{2}$ mediates RNA ejection from the capsid and its penetration into the bacteria cytosol using the pilus canal.

The $A_{2}$ protein was found to block the bacterial MurA enzyme of the murein precursor biosynthesis pathway, thereby promoting host cell lysis $[75,76]$. In the absence of a distinct lysis protein in $Q \beta$, the $A_{2}$ is suspected of playing the role of cell lysis. The mechanism of $A_{2}$ mediated cell lysis is not clear. Nevertheless, it has been shown that overexpression of $A_{2}$ might trigger cell lysis. The entire cDNA of the $Q \beta$ phage was cloned into several plasmids and used to produce phage without lysis of the host cell. Together, with the promising new advances in evolution and the uncover on the $Q \beta$ genome, we suggest that more factors than $\mathrm{A}_{2}$ mediating cell lysis are imminent [55-58,77-80].

\subsubsection{Contribution in Panning for Phage Display}

Phage display libraries can be screened against several targets, including purified biomolecules (antibody, receptors), peptides binding to biological targets like cells or tissues, peptides binding to nonbiological targets like semiconductors and even environmental pollutant insecticides such as imidacloprid. Conventionally, peptides recognizing a target of interest are enriched from phage display libraries through an affinity selection-based procedure referred to as bio-panning. During this screening process, a population of recombinant phage particles is incubated with the target for a period of time, after which unbound targets are removed through a series of stringent washing steps. Different elution conditions are used to improve recombinant phage recovery from the immobilized target. Tight antibody-antigen $(\mathrm{Ab}-\mathrm{Ag})$ binding and attachment to solid support often requires heated, low $\mathrm{pH}$-value buffer treatment [1-10] that frequently reduces the viable variants. We have succeeded in establishing an improved, optimized subtractive panning method to select and enrich antibody-specific antigens more efficiently, without any elution [55]. Our method of panning using the recombinant $Q \beta$ display platform, the $A_{2}$ protein promotes infection while the phage variant is attached to the target, creating a unique and novel strategy for biopanning [55].

\subsection{Coliphage $Q \beta$ Coat Protein}

\subsubsection{Structure and Domain}

The genome of $Q \beta$ is surrounded by a protective icosahedral shell that comprises 178 capsomers. Normally, the number of capsomers expected to make up a perfect symmetry is 180 . However, there is a subtraction as a result of $\mathrm{Cp}$ dimer associated with the genomic RNA represented now by $A_{2}$ protein [81]. Structurally, the capsomer is made up of 132 amino acids, that form a major core with a five-stranded anti parallel $\beta$-sheet, which is surrounded by a hairpin and two contiguous $\beta$-helices [82-84]. Disulfide bonds (S-S) link the capsomers into covalent pentamers and hexamers [84] in a stoichiometric ratio of 12:20, which is well-known in crystal structural studies of this major protein.

\subsubsection{Function of Domain}

The major role of the $\mathrm{Cp}$ is to protect the RNA from any degradation and unfavorable environmental conditions. The $\mathrm{Cp}$ plays no other major role in the infection process. The presence of the phage particles on the pilus actively triggers the retraction necessary for RNA penetration and infection initiation. Additionally, the overexpression of $\mathrm{Cp}$ or capsids can induce cell lysis by bursting, as with any other viral infection system. 


\subsubsection{Contribution to the RNA Display System}

The $\mathrm{Cp}$ provides a platform for the exposition of a foreign peptide. The $\mathrm{Cp}$ is the major component of the platform and is therefore, the backbone of this RNA display system. The icosahedral shell of $Q \beta$ formed by the capsid polymer of the $C p$, provides an equal distribution of the displayed peptides needed for genetic economy and avidity for immune related molecules.

\subsection{Coliphage $Q \beta$ Read-Through or $A_{1}$ Protein}

\subsubsection{Structure and Domain}

The crystal structure of the read-through domain of the $\mathrm{A}_{1}$ protein was determined at a $1.8 \AA$ resolution [85]. The $\mathrm{A}_{1}$ protein represents a C-terminally extended version of capsid protein that contains 12 copies $[55,86]$. Structurally, the $\mathrm{A}_{1}$ is roughly globular in shape, with a mixed $\alpha / \beta$ architecture that is not observed in any other proteins [85]. The $\mathrm{N}$-terminal part of the extension forms an unusually long polyproline type II helix [85-87]. In cryo-EM reconstructions of $Q \beta$, there are no traces of the $A_{1}$ extension, suggesting that copies of $A_{1}$ might be flexibly attached and randomly distributed in individual phage particles. The read-through domain of the $A_{1}$ protein is made up of five-stranded $\beta$-barrels, a $\beta$-hairpin, and a three-stranded $\beta$-sheet [85-87].

\subsubsection{Functional Domains}

The $A_{1}$ protein is required for infection, but the exact function of the $A_{1}$ protein is unknown. The $A_{1}$ protein is a read-through product of the coat gene stop codon [86]. It is expressed through incorrect reading of the leaky stop codon of the coat protein by the replicase [86]. The occasional read-through mechanism is a means of regulation and is an advanced step in phage evolution, which is very important for the evolutionary phage display system described here and is unique to this type of phages. The long stretch residues of polyproline type II helix are known to foster protein-protein and protein-nucleic acid interactions, which is crucial for mature phage formation [85-87].

\subsubsection{Contribution to the $\mathrm{Q} \beta$ Phage Display Platform}

The $A_{1}$ protein shares the same initiation codon with the coat protein and is produced during the UGA stop codon triplet (about 400 nucleotides from the initiation) readthrough [86-89]. In addition, it is suppressed by a low level of translation, where the coat protein's UGA stop codon triplet (about 400 nucleotides from the initiation) ribosome misincorporates tryptophan [86]. This suppression of the stop and extension of translation is the target of foreign gene insertion for phage display. We have successfully deleted up to 150 nucleotides at the $\mathrm{C}$-terminal of the $\mathrm{A}_{1}$ gene without disrupting infectivity and shape of $\mathrm{Q} \beta$ particles formed. So far, up to 300 nucleotides can been added at the C-terminal end of the $A_{1}$ protein [55-57]. Thus, the $A_{1}$ protein as the minor coat protein serves to present the inserted probe upon the surface of the recombinant phage, thereby playing a critical role not only in this novel technology but equally in the directed evolutionary phage display system.

\subsection{Coliphage $Q \beta$ Replicase Protein}

\subsubsection{Structure}

The replicase protein of $Q \beta$ is an RNA dependent RNA polymerase (RdRp). The phage genome encodes only for the $\beta$-subunit of the $R d R p$ replicase. Replicase is a holoenzyme made up of four subunits consisting of a $65 \mathrm{kDa} \beta$-subunit encoded by the phage and three others host encoded subunits, including the $70 \mathrm{kDa} \alpha$ ribosomal protein (S1), the $45 \mathrm{kDa}$ elongation factor, $\gamma$ (EF-Tu) and $35 \mathrm{kDa}$ elongation factor $\delta$ (EF-Ts) [90]. The S1- $\gamma$ subunit forms part of the bacterial $70 \mathrm{~S}$ ribosome and is one of 21 proteins that are involved in the translation of mRNA in the cell after transcription. The sedimentation ratio of the $70 \mathrm{kDa} S 1$ protein is lower than anticipated, due to its elongated shape [91]. Overall, four antiparallel $\beta$-sheets and six $\alpha$-helices form the finger domain. Then, two bundles of $3 \alpha$-helices and 3 
antiparallel $\beta$-sheets form the thumb. In total, five antiparallel $\beta$-sheets flanked by four $\alpha$-helices form the palm [92].

\subsubsection{Subunit Definition}

The $\beta$-subunit is made up of 3 domains, including a finger, thumb, and palm. The two elongation factor subunits $\gamma$ and $\delta$ (EF-Tu and EF-Ts) are bound tightly through hydrophobic interactions to both the finger and thumb domains [90,93]. Specificity is assured between the template and polymerase by the interaction between the virus and the host. The right-handed S1 protein structure is made up of a finger, thumb, and palm domain $[70,94]$. Translational elongation factor subunit $\gamma$ binds to aminoacylated tRNAs (aatRNA) and subsequently moves them to the correct position on the ribosome A-site, by forming a ternary complex of EF-Tu: GTP: aatRNA [94]. Hydrolyzing GTP to GDP+ inorganic phosphate provides the energy to form this complex and for its release from the ribosome, thus leading to accurate translation [95]. The second elongation factor of E. coli, elongation factor subunit $\delta$, is another factor allowing the hydrolsis of GTP to GDP. The release of the bound GDP by elongation factor subunit $\gamma$ allows it to be recycled and to bind a new GTP, which then catalyzes another aatRNA.

When $Q \beta$ phage infects a bacterial host cell, the three subunits of the bacteria replicative enzymes are hijacked by the $\beta$-subunit thereby forming a replicase holoenzyme complex [96]. Here the S1 becomes the $\alpha$ subunit while the EF-Tu, and EF-Ts become the $\gamma$ and $\delta$ subunits, respectively. The core complex of the replicase is therefore made up of the $\beta$ subunit, EF-Tu and EF-Ts which in combination performs the function of polymerization [92-96]. There is also a 102 amino acid enzyme host factors (HF1) which is encoded by the bacteria $h f q$ gene. This factor is required for the initiation of replication and must be present for replication to occur [97]. During the replication process, the ratio between HF1 and the RNA is the rate determining factor instead of the ratio between RNA and the replicase $[97,98]$. For replication of $\mathrm{Q} \beta$ 's positive-stranded genome to begin, the $215 \mathrm{kDa}$ replicase holoenzyme must be completely assembled from the $\mathrm{S} 1$ ribosomal protein, as well as the EF-Tu and EF-Ts elongation factors. Complementary negative stranded RNA is first synthesized, and this will be used as the template to synthesize more positive stranded RNA, eventually serving as mRNA. During replication process, both the positive and negative strands act as templates, implying that after each round of replication, there is doubling of the phage genome $[15,16,96] . Q \beta$ can use both positive and negative stranded RNA and replicase to amplify its genome $10^{4}$-fold in less than an hour. This signifies an exponential growth rate driven by a strong replicative strength.

\subsubsection{Contribution to Evolution and Phage Display}

$\mathrm{Q} \beta$ 's replicase is not like many other replicases, having some unique characteristics. Additionally, its $\beta$-subunit can select its own RNA template amongst a large amounts of other host RNAs. The replicase replicates only its own RNA by making it more than $10^{4}$ times in less than an hour. These two steps are also done without using endogenous primers $[99,100]$. S1 protein and the EF-Tu recognize the template. Strand recognition by EF-Tu: EF-Ts is through the CCC motif of the CCCA sequence which is located on the $3^{\prime}$ end of the RNA template [100]. Equally, this recognition is done on the recombinant RNA as well and is important in the replication of any vector used for this RNA phage display. The function of polymerization occurs once the $3^{\prime}$ bound end of the template enters the replicase initiation site [96-98]. Minus strands are not recognized by ribosomes, unlike the plus strands, and therefore must undergo a different mechanism of replication. The plus strand will replicate in equal amounts along the minus strand if HF1 is in excess. Replication is a linear process. Once the plus strand is copied by the replicase and the replication is terminated, the newly obtained minus strand then becomes a template through a switching or is a free-floating minus strand. At the free $3^{\prime}$ end, an A residue is added post transcriptionally $[75,101]$. The RdRp lacks the proofreading activity, which contributes greatly to the existence of $\mathrm{Q} \beta$ phage as quasi-species [42-53]. The library 
variation is favored by the RdRp in the RNA phage display library. Certainly, the RdRp will be a key player in the adaptation of a displayed probe to its target during the process of amplification and novel panning with the $\mathrm{Q} \beta$ phage display.

\section{Coliphage $Q \beta$ Display System}

\subsection{Overall Methodology: Features and Emphasis}

Although generating recombinant RNA (rRNA) vectors for phage display is very challenging, the RNA phage remains an ideal candidate for IVE. To overcome this challenge, our consortium has optimized a combination of three varieties of plasmids containing the reverse engineered full cDNA of the $\mathrm{Q} \beta$ phage. All genetic engineering intending to generate vectors for phage RNA phage display is carried out on these plasmids. We have successfully created a multiple cloning site at the end of the $\mathrm{A}_{1}$ gene where unique restriction enzymes can be used for gene probe insertion. Traditionally, this multiple cloning site, present on the minor protein gene, is shared by all four proteins (p3, p6, p7, p9) of M13 phage. Additionally, these minor coat proteins exercise a combined vital role in the infection cycle of M13 and in display technology. The facts that protein (pIII) plays a role in the display technology by exposing the probes and is implicated in the initiation of infection cycle of the M13 phage are major drawbacks of the traditional M13 system. The multifunctionality of pIII compromises the platform, especially when used in displaying a library of peptides. This compels the use of acidic buffers for elution and neutralizing during biopanning. These harsh conditions are detrimental, both to infectivity and the affinity of phage variants arising from library. In contrast, the $A_{2}$ protein of $Q \beta$ is involved in initiating the phage life cycle. In the RNA $Q \beta$ phage system, the two major functions of infection initiation and bioprobe display played by the pIII in the M13 phage display system are split between the $A_{1}$ and $A_{2}$ proteins. The sharing of these functions between $A_{1}$ and $A_{2}$, increases the specificity of $Q \beta$ phage display biotechnology and improves both the affinity and infectivity of phage variants during $Q \beta$ phage library production.

Being the most attractive $R d R p$, the $Q \beta$ replicase with its well-known promiscuity, is the key element of this RNA $Q \beta$ phage display system because it is responsible for driving diversity and inducing the adaptability of the variant populations to their corresponding target(s). These minor protein $\left(\mathrm{A}_{1}\right.$ and $\left.\mathrm{A}_{2}\right)$ mediated features during $\mathrm{Q} \beta$ phage display are unique and novel. The uniqueness of the RNA coliphage $Q \beta$ display system renders it a powerful tool in IVE of peptides, antibodies, and nanobodies.

Another feature of the $Q \beta$ phage display system is the icosahedral structure of variants and the equidistance position of the fusion protein $\mathrm{A}_{1}$-probe(s) on the surface of the phage which is an attractive tool for affinity or avidity study for appropriate target. This $\mathrm{A}_{1}$-probe arrangement eliminates the need for harsh acidic elutions during the recombinat phages screening process. The novel biopanning strategy developed with $Q \beta$ is quick, permitting more than 10 possible rounds per day which, significantly, facilitates the implementation of RNA phage display in synthetic biology. During this novel biopanning strategy, the elution of variants is done by infection, which avoids the harsh conditions associated with acidic treatment and neutralization on this major step in the conventional panning.

\subsection{Determining Steps in the RNA $Q \beta$ Display System}

As a new tool in IVE, a critical pre-requisite is the maximum peptide(s) size potentially acceptable upon the exterior surface of the recombinant $\mathrm{Q} \beta$ phage particle without compromising its infectivity. Another essential necessity would be the relation between peptide motives and the ability of the recombinant $Q \beta$ phage to expose them. Through sequential deletions in the $A_{1}$ gene, we have succeeded to create more room for the insertion of foreign DNA. However, the effect of such deletions (gene size reduction) in $\mathrm{A}_{1}$ must be ascertained to further improve the platform. Given the variation observed in phage host cell expression, where different host cells are tested, including E. coli K12, Q13, Hfrh, and HB101, $A_{2}$ protein's involvement in host cell lysis cannot be the only means through which $Q \beta$ mediates host cell lysis. Knowing the mechanism of $Q \beta$ mediated host lysis 
during infection would help to improve the production and the effective use of the $Q \beta$ display platform. The high rate of mutation within this phage display platform could be an indication of the extent of evolution, which must eventually be determined for the system. Addressing these listed knowledge gaps within the coliphage $Q \beta$ display system will further augment its suitability and uniqueness for directed evolutionary biotechnology and IVE investigations.

\section{Application in Directed Evolution and Conclusion Application}

We have reviewed the genome and proteins of the coliphage $Q \beta$ and proposed ways to improve its potential to display peptides, antibodies, nanobodies, and different library formats through genetic engineering. In contrast to the traditional display with DNA phages, this new system has multiple advantages ranging from the rRNA construction, phages production, to biopanning for variants selection. This has broad application in virology especially through displaying epitopes (mimotopes) of challenging RNA viruses which would help in the development of both vaccines and optimize novel biomarkers for point of care kits or theragnosis. In cancer biology, random library display can lead to the selection of major immune checkpoint inhibitors for therapeutic purposes. Generalized library screens can aid in developing peptides as new drugs from library selection and evolution. The introduction of new biomolecules resulting from mixtures of selected peptides from novel libraries and appropriate nanoparticles becomes feasible. Similarly, construction of novel biosensors by evolving peptides to detect molecules and life-threatening agents can be developed as well (See Figure 2 attached) in the environment. The uniqueness of the RNA coliphage $\mathrm{Q} \beta$ display system comes from its inherent structure, biology, and its potential broad application in live sciences.

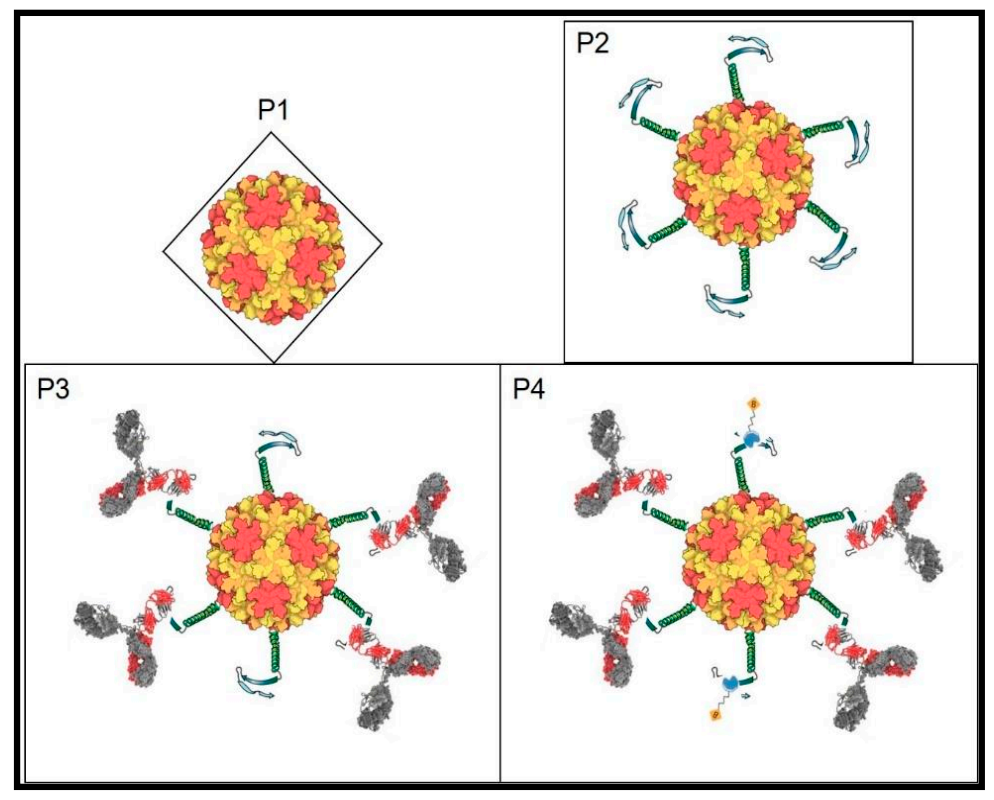

Figure 2. RNA coliphage $\mathrm{Q} \beta$ structure with $\mathrm{T}=3 ; \mathrm{P} 1: \mathrm{Q} \beta$ phage icosahedral shell; $\mathrm{P} 2$ : $\mathrm{Q} \beta$ phage (P1) displaying a probe and a transducer peptides joined by a linker all fused to the end of the $\mathrm{A}_{1}$ protein; P3: RNA Q $\beta$ phage exposing the probe (here an RNA virus epitope) complexing its corresponding IgG through the variable domain and hiding the transducer; P4: P3 detection of the remaining transducer by binding to the analyte in real time and quantifiable. Without probe-target (here antibody-antigen) complex, the detection is $100 \%$ measurable (transducer saturated with detector) and the opposite (antibodies compete and hide the transducer) will be subtracted to quantify the target detected by the biosensor. 


\section{Conclusions}

The RNA coliphage display concept and methodology presented here, though in its infancy, represents a novel breakthrough strategyin phage display biotechnology that will strengthen molecular evolution, thereby expediting biomolecule identification and valorization. The major biotechnological applications stem from the direct evolution of these biomolecules on targets. The RNA phage expressing the probe binds to the target, while being allowed to infect the host cell for genomic replication and expression, thus leading to the production of probe progenies. Any pressure on the target-probe connection is obvious seocndary to new progenies, translating into direct evolution. For the first time, binding of the probe (phenotype) to its target, in connection with external pressure on the gene library (genotype), and continuous replication (directed evolution) combines to make RNA coliphage $Q \beta$ to be both unique and feasible. Additionally, this tool will help mimic, measure, and demonstrate live evolutionary concepts, which can result in developing novel evolved biologics crucial for new drug discovery against challenging diseases.

Author Contributions: A.B.W. conceived and designed the review. A.B.W., M.T.C., G.W.N., J.M.C., and N.A.-A. performed the articles search. A.B.W. and M.T.C. analyzed the title and subtitles. A.B.W., M.T.C., and G.W.N. contributed materials/analysis tools. A.B.W., M.T.C., G.W.N., J.M.C., and N.A.-A. wrote and corrected the review paper. A.B.W. prepared the figures for biosensor and the $Q \beta$ genome organization. All authors have read and agreed to the published version of the manuscript.

Funding: Grant: NSF-AGEP \#1432991. The Faculty Startup Fund from the Precision Health Initiative (PHI) of the Indiana University School of Medicine (IUSM).

Acknowledgments: The Faculty Startup Fund from the Precision Health Initiative (PHI) and Department of Biochemistry and Molecular Biology of the Indiana University School of Medicine (IUSM), 635 Barnhill Drive, MS1017Q Lab MS1015, Indianapolis, IN, 46202.

Conflicts of Interest: The authors report no conflict of interest in the work of this review paper.

\section{References}

1. Smith, G.P. Filamentous fusion phage: Novel expression vectors that display cloned antigens on the virion surface. Science 1985, 228, 1315-1317. [CrossRef]

2. Smith, G.P.; Petrenko, V.A. Phage display. Chem. Rev. 1997, 97, 391-410. [CrossRef]

3. Fernandez-Gacio, A.; Uguen, M.; Fastrez, J. Phage display as a tool for the directed evolution of enzymes. Trends Biotechnol. 2003, 21, 408-414. [CrossRef]

4. Citorik, R.J.; Mimee, M.; Lu, T.K. Bacteriophage-based synthetic biology for the study of infectious diseases. Curr. Opin. Microbiol. 2014, 19, 59-69. [CrossRef]

5. Barbu, E.M.; Cady, K.C.; Hubby, B. Phage therapy in the era of synthetic biology. Cold Spring Harb. Perspect. Biol. 2016, 8, a023879. [CrossRef]

6. Bertani, G. Lysogenic versus lytic cycle of phage multiplication. In Cold Spring Harbor Symposia on Quantitative Biology; Cold Spring Harbor Laboratory Press: New York, NY, USA, 1953; Volume 18, pp. 65-70.

7. Wang, N.; Dykhuizen, D.E.; Slobodkin, L.B. The evolution of phage lysis timing. Evol. Ecol. 1996, 10, 545-558. [CrossRef]

8. Chibani-Chennoufi, S.; Bruttin, A.; Dillmann, M.L.; Brüssow, H. Phage-host interaction: An ecological perspective. J. Bacteriol. 2004, 186, 3677-3686. [CrossRef]

9. Böttger, V.; Böttger, A.; Howard, S.F.; Picksley, S.M.; Chène, P.; Garcia-Echeverria, C.; Hochkeppel, H.K.; Lane, D.P. Identification of novel mdm2 binding peptides by phage display. Oncogene 1996, 13, 2141-2147.

10. Koivunen, E.; Arap, W.; Rajotte, D.; Lahdenranta, J.; Pasqualini, R. Identification of receptor ligands with phage display peptide libraries. J. Nucl. Med. 1999, 40, 883-888.

11. Li, Y.; Moysey, R.; Molloy, P.E.; Vuidepot, A.L.; Mahon, T.; Baston, E.; Dunn, S.; Liddy, N.; Jacob, J.; Jakobsen, B.K.; et al. Directed evolution of human T-cell receptors with picomolar affinities by phage display. Nat. Biotechnol. 2005, 23, 349-354. [CrossRef]

12. Bratkovič, T. Progress in phage display: Evolution of the technique and its applications. Cell. Mol. Life Sci. 2010, 67, 749-767. [CrossRef]

13. Blanco, L.; Bernad, A.; Lázaro, J.M.; Martín, G.; Garmendia, C.; Salas, M. Highly efficient DNA synthesis by the phage $\phi 29$ DNA polymerase: Symmetrical mode of DNA replication. J. Biol. Chem. 1989, 264, 8935-8940. [CrossRef]

14. Cowart, M.; Gibson, K.J.; Allen, D.J.; Benkovic, S.J. DNA substrate structural requirements for the exonuclease and polymerase activities of prokaryotic and phage DNA polymerases. Biochemistry 1989, 28, 1975-1983. [CrossRef]

15. Landers, T.A.; Blumenthal, T.; Weber, K. Function and structure in ribonucleic acid phage Q $\beta$ ribonucleic acid replicase: The roles of the different subunits in transcription of synthetic templates. J. Biol. Chem. 1974, 249, 5801-5808. [CrossRef] 
16. Young, R.A.; Blumenthal, T. Phage Q-beta ribonucleic acid replicase. Subunit relationships determined by intramolecular cross-linking. J. Biol. Chem. 1975, 250, 1829-1832. [CrossRef]

17. Garmendia, C.; Bernad, A.; Esteban, J.A.; Blanco, L.; Salas, M. The bacteriophage phi 29 DNA polymerase, a proofreading enzyme. J. Biol. Chem. 1992, 267, 2594-2599. [CrossRef]

18. Reddy, M.K.; Weitzel, S.E.; Von Hippel, P.H. Processive proofreading is intrinsic to T4 DNA polymerase. J. Biol. Chem. 1992, 267, 14157-14166. [CrossRef]

19. Inokuchi, Y.; Hirashima, A.K. Interference with viral infection by defective RNA replicase. J. Virol. 1987, 61, 3946-3949. [CrossRef]

20. Kajitani, M.; Ishihama, A. Identification and sequence determination of the host factor gene for bacteriophage Q $\beta$. Nucleic Acids Res. 1991, 19, 1063-1066. [CrossRef]

21. d'Herelle, F.H. Comptes Rendu. Acad. Sci. Paris 1917, 165, 373-375.

22. d'Herelle, M.F. Sur un microbe invisible antagoniste des bacilles dysentériques. Acta Kravsi 1961, 1, 1.

23. Stent, G.S. Molecular Biology of Bacterial Viruses. Available online: https://www.cabdirect.org/cabdirect/abstract/19640101695 (accessed on 18 February 2021).

24. Summers, W.C. The strange history of phage therapy. Bacteriophage 2012, 2, 130-133. [CrossRef]

25. Suttle, C.A. Viruses in the sea. Nature 2005, 437, 356-361. [CrossRef]

26. Salmond, G.P.; Fineran, P.C. A century of the phage: Past, present and future. Nat. Rev. Microbiol. 2015, 13, 777-786. [CrossRef]

27. Chibani, C.M.; Farr, A.; Klama, S.; Dietrich, S.; Liesegang, H. Classifying the unclassified: A phage classification method. Viruses 2019, 11, 195. [CrossRef] [PubMed]

28. Moineau, S.; Borkaev, M.; Holler, B.J.; Walker, S.A.; Kondo, J.K.; Vedamuthu, E.R.; Vandenbergh, P.A. Isolation and characterization of lactococcal bacteriophages from cultured buttermilk plants in the United States. J. Dairy Sci. 1996, 79, 2104-2111. [CrossRef]

29. Ackermann, H.W. Phage classification and characterization. In Bacteriophages; Humana Press: Totowa, NJ, USA, 2009; pp. 127-140.

30. Salivar, W.O.; Tzagoloff, H.; Pratt, D. Some physical-chemical and biological properties of the rod-shaped coliphage M13. Virology 1964, 24, 359-371. [CrossRef]

31. Tzagoloff, H.; Pratt, D. The initial steps in infection with coliphage M13. Virology 1964, 24, 372-380. [CrossRef]

32. Messing, J.; Gronenborn, B.; Müller-Hill, B.; Hopschneider, P.H. Filamentous coliphage M13 as a cloning vehicle: Insertion of a HindII fragment of the lac regulatory region in M13 replicative form in vitro. Proc. Natl. Acad. Sci. USA 1977, 74, 3642-3646. [CrossRef]

33. Messing, J. New M13 vectors for cloning. Methods Enzymol. 1983, 101, 20-78. [PubMed]

34. Goldsmith, M.E.; Konigsberg, W.H. Adsorption protein of the bacteriophage fd: Isolation, molecular properties, and location in the virus. Biochemistry 1977, 16, 2686-2694. [CrossRef] [PubMed]

35. Lopez, J.; Webster, R.E. Morphogenesis of filamentous bacteriophage f1: Orientation of extrusion and production of polyphage. Virology 1983, 127, 177-193. [CrossRef]

36. Rakonjac, J.; Model, P. Roles of pIII in filamentous phage assembly. J. Mol. Biol. 1998, 282, 25-41. [CrossRef]

37. Rakonjac, J.; Feng, J.N.; Model, P. Filamentous phage are released from the bacterial membrane by a two-step mechanism involving a short C-terminal fragment of pIII. J. Mol. Biol. 1999, 289, 1253-1265. [CrossRef]

38. Palasingam, K.; Shaklee, P.N. Reversion of Q beta RNA phage mutants by homologous RNA recombination. J. Virol. 1992, 66, 2435-2442. [CrossRef]

39. Malpica, J.M.; Fraile, A.; Moreno, I.; Obies, C.I.; Drake, J.W.; García-Arenal, F. The rate and character of spontaneous mutation in an RNA virus. Genetics 2002, 162, 1505-1511.

40. Moya, A.; Elena, S.F.; Bracho, A.; Miralles, R.; Barrio, E. The evolution of RNA viruses: A population genetics view. Proc. Natl. Acad. Sci. USA 2000, 97, 6967-6973. [CrossRef]

41. Elena, S.F.; Bedhomme, S.; Carrasco, P.; Cuevas, J.M.; de la Iglesia, F.; Lafforgue, G.; Lalić, J.; Pròsper, À.; Tromas, N.; Zwart, M.P. The evolutionary genetics of emerging plant RNA viruses. Mol. Plant Microbe Interact. 2011, 24, 287-293. [CrossRef]

42. Domingo, E.; Escarmís, C.; Sevilla, N.; Moya, A.; Elena, S.F.; Quer, J.; Novella, I.S.; Holland, J.J. Basic concepts in RNA virus evolution. FASEB J. 1996, 10, 859-864. [CrossRef] [PubMed]

43. Darwin, C.; Wallace, A.R. Evolution by natural selection. Evol. Nat. Sel. 1958, 1, 1.

44. Mills, D.R.; Peterson, R.L.; Spiegelman, S. An extracellular Darwinian experiment with a self-duplicating nucleic acid molecule. Proc. Natl. Acad. Sci. USA 1967, 58, 217. [CrossRef] [PubMed]

45. Popper, K. Natural selection and the emergence of mind. Dialectica 1978, 32, 339-355. [CrossRef]

46. Tsimring, L.S.; Levine, H.; Kessler, D.A. RNA virus evolution via a fitness-space model. Phys. Rev. Lett. 1996, 76, 4440. [CrossRef] [PubMed]

47. Burch, C.L.; Chao, L. Evolution by small steps and rugged landscapes in the RNA virus $\phi 6$. Genetics 1999, 151, 921-927.

48. Domingo, E.; Holland, J.J. RNA virus mutations and fitness for survival. Annu. Rev. Microbiol. 1997, 51, 151-178. [CrossRef]

49. Eigen, M. On the nature of virus quasispecies. Trends Microbiol. 1996, 4, 216-218. [CrossRef]

50. Eigen, M. Viral quasispecies. Sci. Am. 1993, 269, 42-49. [CrossRef]

51. Domingo, E. Quasispecies theory in virology. J. Virol. 2002, 76, 463-465. [CrossRef]

52. Solé, R.V.; Ferrer, R.; González-García, I.; Quer, J.; Domingo, E. Red queen dynamics, competition and critical points in a model of RNA virus quasispecies. J. Theor. Biol. 1999, 198, 47-59. [CrossRef] 
53. Domingo, E.; Holland, J.J.; Biebricher, C.; Eigen, M. Quasispecies: The concept and the word. Mol. Basis Virus Evol. 1995, 1, 171-180.

54. Waffo, A.B. Evolutionary RNA-coliphage Qß [Q-beta] Display: Expression Biopathway in E. Coli; Cuvillier Verlag: Goettingen, Germany, 2004.

55. Skamel, C.; Aller, S.G.; Waffo, A.B. In vitro evolution and affinity-maturation with coliphage Q $\beta$ display. PLoS ONE 2014, 9, e113069. [CrossRef]

56. Källberg, M.; Wang, H.; Wang, S.; Peng, J.; Wang, Z.; Lu, H.; Xu, J. Template-based protein structure modeling using the RaptorX web server. Nature Protocols 2012, 7, 1511-1522. [CrossRef]

57. Lissom, A.; Ouambo, H.F.; Megnekou, R.; Okeke, M.I.; Ngu, L.N.; Netongo, P.M.; Ngoh, A.A.; Sanders, C.A.; Bawage, S.; Tchouangueu, T.F.; et al. Comparative analysis of igg responses to recombinant Q $\beta$ phage displayed MSP3 and UB05 in dual HIV-malaria infected adults living in areas differing in malaria transmission intensities. bioRxiv 2018. [CrossRef]

58. Waffo, A.B.; Lissom, A.; Ouambo, H.F.; Ngu, L.N.; Ngoh, A.A. Surface Engineering of the RNA Coliphage Q $\beta$ to Display Plasmodium Falciparum Derived Asexual Blood Stage Antigens UB05 and Merozoite Surface Protein 3. Clin. Microbiol. 2018, 7, 2. [CrossRef]

59. Priano, C.; Arora, R.; Butke, J.; Mills, D.R. A complete plasmid-based complementation system for RNA coliphage Q $\beta$ : Three proteins of bacteriophages Q $\beta$ (group III) and SP (group IV) can be interchanged. J. Mol. Biol. 1995, 249, 283-297. [CrossRef]

60. Witherell, G.W.; Uhlenbeck, O.C. Specific RNA binding by Q. beta. coat protein. Biochemistry 1989, 28, 71-76. [CrossRef] [PubMed]

61. Gorzelnik, K.V.; Cui, Z.; Reed, C.A.; Jakana, J.; Young, R.; Zhang, J. Asymmetric cryo-EM structure of the canonical Allolevivirus Qß reveals a single maturation protein and the genomic ssRNA in situ. Proc. Natl. Acad. Sci. USA 2016, 113, 11519-11524. [CrossRef] [PubMed]

62. Crawford, E.M.; Gesteland, R.F. The adsorption of bacteriophage R-17. Virology 1964, 22, 165-167. [CrossRef]

63. Poot, R.A.; Tsareva, N.V.; Boni, I.V.; Van Duin, J. RNA folding kinetics regulates translation of phage MS2 maturation gene. Proc. Natl. Acad. Sci. USA 1997, 94, 10110-10115. [CrossRef]

64. Reed, C.A. Characterization of A2: The Lysis Protein of SsRNA Phage Qbeta. Ph.D. Thesis, Texas A \& M University, College Station, TX, USA, 2012.

65. Klovins, J.; Van Duin, J. A long-range pseudoknot in Qß RNA is essential for replication. J. Mol. Biol. 1999, $294,875-884$. [CrossRef] [PubMed]

66. Rumnieks, J.; Tars, K. Crystal structure of the maturation protein from bacteriophage Qß. J. Mol. Biol. 2017, 429, 688-696. [CrossRef]

67. Rūmnieks, J.; Tārs, K. Protein-RNA interactions in the single-stranded RNA bacteriophages. Virus Protein Nucl. Complexes 2018, 88, 281-303.

68. Tars, K. ssRNA Phages: Life Cycle, Structure and Applications. In Biocommunication of Phages; Springer: Cham, Switzerland, 2020; pp. 261-292.

69. Reed, C.A.; Langlais, C.; Kuznetsov, V.; Young, R. Inhibitory mechanism of the Qß lysis protein A2. Mol. Microbiol. 2012, 86, 836-844. [CrossRef] [PubMed]

70. Takeshita, D.; Tomita, K. Assembly of $\mathrm{Q} \beta$ viral RNA polymerase with host translational elongation factors EF-Tu and-Ts. Proc. Natl. Acad. Sci. USA 2010, 107, 15733-15738. [CrossRef]

71. Morais, M.C. Breaking the symmetry of a viral capsid. Proc. Natl. Acad. Sci. USA 2016, 113, 11390-11392. [CrossRef]

72. Chamakura, K.R.; Tran, J.S.; O’Leary, C.; Lisciandro, H.G.; Antillon, S.F.; Garza, K.D.; Tran, E.; Min, L.; Young, R. Rapid de novo evolution of lysis genes in single-stranded RNA phages. Nat. Commun. 2020, 11, 1-11. [CrossRef]

73. Serwer, P.; Wright, E.T.; Demeler, B.; Jiang, W. States of phage T3/T7 capsids: Buoyant density centrifugation and cryo-EM. Biophys. Rev. 2018, 10, 583-596. [CrossRef] [PubMed]

74. Golmohammadi, R.; Fridborg, K.; Bundule, M.; Valegård, K.; Liljas, L. The crystal structure of bacteriophage Q $\beta$ at $3.5 \AA$ resolution. Structure 1996, 4, 543-554. [CrossRef]

75. Bernhardt, T.G.; Wang, N.; Struck, D.K.; Young, R. Breaking free:"protein antibiotics” and phage lysis. Res. Microbiol. 2002, 153, 493-501. [CrossRef]

76. Karnik, S.; Billeter, M. The lysis function of RNA bacteriophage Qbeta is mediated by the maturation (A2) protein. EMBO J. 1983, 2, 1521-1526. [CrossRef]

77. Mills, D.R.; Priano, C.; Merz, P.A.; Binderow, B.D. Q beta RNA bacteriophage: Mapping cis-acting elements within an RNA genome. J. Virol. 1990, 64, 3872-3881. [CrossRef]

78. Taniguchi, T.; Palmieri, M.; Weissmann, C. $Q \beta$ DNA-containing hybrid plasmids giving rise to $Q \beta$ phage formation in the bacterial host. Nature 1978, 274, 223-228. [CrossRef]

79. Klovins, J.; Berzins, V.; Van Duin, J. A long-range interaction in Qbeta RNA that bridges the thousand nucleotides between the M-site and the 3'end is required for replication. RNA 1998, 4, 948-957. [CrossRef]

80. Lázaro, E.; Arribas, M.; Cabanillas, L.; Román, I.; Acosta, E. Evolutionary adaptation of an RNA bacteriophage to the simultaneous increase in the within-host and extracellular temperatures. Sci. Rep. 2018, 8, 1-9. [CrossRef]

81. Stoll, E.; Wilson, K.J.; Reiser, J.; Weissmann, C. Revised amino acid sequence of Qbeta coat protein between positions 1 and 60. J. Biol. Chem. 1977, 252, 990-993. [CrossRef] 
82. Ni, C.Z.; White, C.A.; Mitchell, R.S.; Wickersham, J.; Kodandapani, R.; Peabody, D.S.; Ely, K.R. Crystal structure of the coat protein from the GA bacteriophage: Model of the unassembled dimer. Protein Sci. 1996, 5, 2485-2493. [CrossRef] [PubMed]

83. Lim, F.; Peabody, D.S. RNA recognition site of PP7 coat protein. Nucleic Acids Res. 2002, 30, 4138-4144. [CrossRef] [PubMed]

84. Shishovs, M.; Rumnieks, J.; Diebolder, C.; Jaudzems, K.; Andreas, L.B.; Stanek, J.; Kazaks, A.; Kotelovica, S.; Akopjana, I.; Pintacuda, G.; et al. Structure of AP205 coat protein reveals circular permutation in ssRNA bacteriophages. J. Mol. Biol. 2016, 428, 4267-4279. [CrossRef]

85. Rumnieks, J.; Tars, K. Crystal structure of the read-through domain from bacteriophage Q $\beta$ A1 protein. Protein Sci. 2011, 20, 1707-1712. [CrossRef]

86. Axelrod, V.D.; Brown, E.; Priano, C.; Mills, D.R. Coliphage Q $\beta$ RNA replication: RNA catalytic for single-strand release. Virology 1991, 184, 595-608. [CrossRef]

87. Barrett, R.W.; Cwirla, S.E.; Ackerman, M.S.; Olson, A.M.; Peters, E.A.; Dower, W.J. Selective enrichment and characterization of high affinity ligands from collections of random peptides on filamentous phage. Anal. Biochem. 1992, 204, 357-364. [CrossRef]

88. Adzhubei, A.A.; Sternberg, M.J.; Makarov, A.A. Polyproline-II helix in proteins: Structure and function. J. Mol. Biol. 2013, 425, 2100-2132. [CrossRef]

89. Katz, M.J.; Gándara, L.; Ezcurra, A.D.L.; Wappner, P. Hydroxylation and translational adaptation to stress: Some answers lie beyond the STOP codon. Cell. Mol. Life Sci. 2016, 73, 1881-1893. [CrossRef]

90. Brown, D.; Gold, L. RNA replication by Q beta replicase: A working model. Proc. Natl. Acad. Sci. USA 1996, 93, 11558-11562. [CrossRef]

91. Bycroft, M.; Hubbard, T.J.; Proctor, M.; Freund, S.M.; Murzin, A.G. The solution structure of the S1 RNA binding domain: A member of an ancient nucleic acid-binding fold. Cell 1997, 88, 235-242. [CrossRef]

92. Takeshita, D.; Tomita, K. Molecular basis for RNA polymerization by Qß replicase. Nat. Struct. Mol. Biol. 2012, 19, 229. [CrossRef]

93. Kashiwagi, A.; Yomo, T. Ongoing phenotypic and genomic changes in experimental coevolution of RNA bacteriophage Q $\beta$ and Escherichia coli. PLoS Genet. 2011, 7, e1002188. [CrossRef] [PubMed]

94. Takeshita, D.; Yamashita, S.; Tomita, K. Molecular insights into replication initiation by Q $\beta$ replicase using ribosomal protein S1. Nucleic Acids Res. 2014, 42, 10809-10822. [CrossRef] [PubMed]

95. Biebricher, C.K.; Luce, R. In vitro recombination and terminal elongation of RNA by Q beta replicase. EMBO J. 1992, 11, 5129-5135. [CrossRef]

96. Blumenthal, T.; Carmichael, G.G. RNA replication: Function and structure of Qbeta-replicase. Annu. Rev. Biochem. 1979, 48, 525-548. [CrossRef] [PubMed]

97. Muffler, A.; Fischer, D.; Hengge-Aronis, R. The RNA-binding protein HF-I, known as a host factor for phage Qbeta RNA replication, is essential for rpoS translation in Escherichia coli. Genes Dev. 1996, 10, 1143-1151. [CrossRef] [PubMed]

98. Hajnsdorf, E.; Boni, I.V. Multiple activities of RNA-binding proteins S1 and Hfq. Biochimie 2012, 94, 1544-1553. [CrossRef] [PubMed]

99. Sumper, M.; Luce, R. Evidence for de novo production of self-replicating and environmentally adapted RNA structures by bacteriophage Qbeta replicase. Proc. Natl. Acad. Sci. USA 1975, 72, 162-166. [CrossRef]

100. Yoshinari, S.; Nagy, P.D.; Simon, A.E.; Dreher, T.W. CCA initiation boxes without unique promoter elements support in vitro transcription by three viral RNA-dependent RNA polymerases. RNA 2000, 6, 698-707. [CrossRef] [PubMed]

101. Bernhardt, T.G.; Wang, N.; Struck, D.K.; Young, R. A protein antibiotic in the phage Q $\beta$ virion: Diversity in lysis targets. Science 2001, 292, 2326-2329. [CrossRef] [PubMed] 